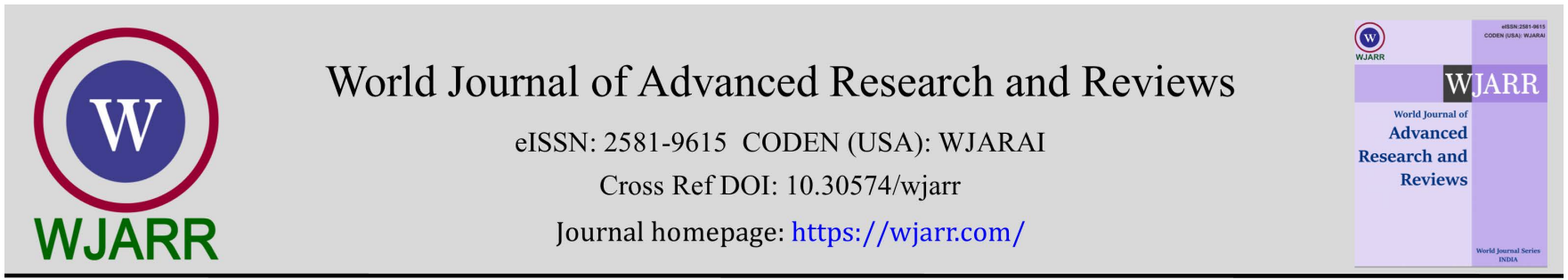

(RESEARCH ARTICLE)

Check for updates

\title{
Efficacy as a growth promoter of Tulsi leaves extract in broiler production with carcass characteristics and hematological profile
}

\author{
Md Tahidul Islam 1, Md Ashraf Zaman Faruk ${ }^{2, *}$, Md Sazzad Hossain ${ }^{1}$ and Dolan Das 1 \\ ${ }^{1}$ Department of Pharmacology, Faculty of Veterinary Science, Bangladesh Agricultural University, Mymensingh-2202, \\ Bangladesh. \\ 2 Department of Anatomy and Histology, Faculty of Veterinary Science, Bangladesh Agricultural University, Mymensingh- \\ 2202, Bangladesh.
}

World Journal of Advanced Research and Reviews, 2021, 11(03), 272-279

Publication history: Received on 13 August 2021; revised on 20 September 2021; accepted on 22 September 2021

Article DOI: https://doi.org/10.30574/wjarr.2021.11.3.0452

\begin{abstract}
This experiment was conducted to investigate the efficacy of tulsi leaves (Ocimum sanctum) extract supplementation in drinking water as a growth promoter in broiler chickens. A total No. of 30 day old Cobb-500 broiler chicks was purchased from local hatchery and after seven days of acclimatization chicks were randomly divided into two groups A and B in equal number. The group A was kept as a control and not treated. The group B was supplemented with tulsi leaves extract with feed and water. Weekly observations were recorded for live body weight gain up to 30 days and hematological tests were performed at 30th day's age of broiler to evaluate the hematological changes between two groups. The initial body weight of groups A and B on 1st day of this experiment were $42.80 \pm 10.31 \mathrm{gm}$ and $42.68 \pm 6.90$ gm respectively and after $30^{\text {th }}$ days of experiment final body weight were $1530 \pm 33.07$ gm and $1600 \pm 44.80 \mathrm{gm}$ respectively; the net body weight gain from $7^{\text {th }}$ day were $1488 \pm 41.12 \mathrm{gm}$ and $1551 \pm 39.29$ gm respectively and economics of production was analyzed and found that net profit per broiler was Tk. 24.51 and Tk. 32.50 respectively. The treatment group B was reported statistically significant (at 1\% level) increased 16.43\% for live body weight than the control group A. The hematological parameters TEC, ESR and PCV value of treatment group showed significant difference, while Hemoglobin $(\mathrm{Hb})$ estimation did not show significant difference from control group. Therefore, the findings of the study results suggest that supplemented with tulsi leaves extract with feed and water can improve the growth performance of broiler.
\end{abstract}

Keywords: Tulsi; Broiler; Growth promoter; Hematological profile

\section{Introduction}

Poultry industry has become an important economic activity and an essential source of protein in many countries including Bangladesh. So, the demand of broiler meat is increasing rapidly as a cheap protein source in contrast of increasing population growth and urbanization. As a result the growth and development of the commercial broiler farming in the country during the last three decades has been spectacular. Eventually, in large-scale rearing system, where poultry are exposed to stressful conditions, problems related to diseases and deterioration of environmental conditions often occur and result in serious economic losses as poultry are vulnerable to potentially pathogenic microorganisms. Therefore, a variety of non-nutritive feed additives are used in broiler production to improve the overall performance, reduce the incidence of disease caused by microorganisms and immune status by eliminating stressful conditions [1]. Low-doses or sub-therapeutic levels of antibiotics in broiler feed have been a common practice

${ }^{*}$ Corresponding author: Md Ashraf Zaman Faruk; E-mail: faruk.unibd@yahoo.com

Department of Anatomy and Histology, Faculty of Veterinary Science, Bangladesh Agricultural University, Mymensingh-2202, Bangladesh.

Copyright (C) 2021 Author(s) retain the copyright of this article. This article is published under the terms of the Creative Commons Attribution Liscense 4.0. 
for more than 50 years to prevent potential disease as well as to robust gut health and improve feed efficiency of broilers $[2]$.

However, many studies have provided clear evidence that indiscriminate use of Antibiotic Growth Promoter (AGP) in broiler feed contributes to the accumulation of antibiotic residues in edible meat thus enter into the human food chain, thereby hastening the emergence of antibiotic-resistant bacteria, which poses a dire risk to consumer health [3,4]. In order to consumer concerns about the food safety and ethics, the European Union has banned the use of antibiotics in animal production since 2006. Other developed countries have also limited the antibiotics use in poultry production and most of the feed industries in the developed countries removed all types of antibiotics from poultry feeds and launched the antibiotic-free labeled feed $[5,6]$.

For this reason, there is considerable research interest in the possible use of natural products, such as essential oils and extracts of edible and medicinal plants, herbs and spices, for the development of new additives in animal feeding. Medicinal plants have been used for centuries before the advent of orthodox medicine. Leaves, flowers, stems, roots, seeds, fruit, and bark can all be constituents of herbal medicines. The medicinal values of these plants lie in their component phytochemicals, which produce definite physiological actions on the human body. The most important of these phytochemicals are alkaloids, tannins, flavonoids and phenolic compounds [7,8]. Considering the hazards of antimicrobials and beneficiary effects of herbs and spices, scientists are again concentrating on the use of our ancient medicinal system to find beneficial herbs and plants, which can be safely used to increase the production.

Tulsi (Ocimum sanctum) is one of such plants, considered to be the "Queen of herbs" due to its greater medicinal values. The plant is reported to possess anti-infertility, anticancer, antibacterial [9], antidiabetic, antifungal, antimicrobial, hepatoprotective, cardioprotective, antiemetic, antioxidant [10], antispasmodic, analgesic, anti-ulcerogenic and ulcer healing properties, adaptogenic [11] and diaphoretic actions [12]. The main constituents responsible for these properties are eugenol, ascorbic acid, ß-carotene, $ß$-sitosterol, palmitic acid and tannins [13,14]. This observation was therefore, designed to study the effects of tulsi (Ocimum sanctum) leave extract in broiler, with a view to establishing as a growth promoter and its safety.

\section{Material and methods}

This experiment was carried out at the Department of Pharmacology, Faculty of Veterinary Science, Bangladesh Agricultural University, Mymensingh. Thirty number of days old Cobb-500 broiler chicks were used in the study and randomly divided into two groups $A$ and $B$ (each group consisting of 15 chicks). The experimental units were kept on a cage system in separate pens. A weighted amount of the ration was offered to the birds twice a day and the left over feed was collected to calculate feed consumption of the birds. Fresh and clean water was made available at all the times. The experiment was conducted according to the completely randomized design and data about per replicate body weight, weekly body weight, weekly feed consumptions and mortality were recorded during the experimental period.

\subsection{Collection and Preparation of fresh juice}

Mature and disease free tulsi (Ocimum sanctum) leaves were collected from BAU Botanical Garden. After washing, the fresh leaves were cut into small pieces by simple scissors and dried in oven and 30gm mixed with water made up to 1 litter. Then boiled it made up to 1 liter and stored in a refrigerator at $4^{\circ} \mathrm{C}$ to preserve the active ingredients of juice.

\subsection{Collection and Management of broilers}

At first, the shed (experimental shed at BAU campus governed by Department of Pharmacology) for rearing broiler chickens was properly prepared i.e., the floor and compartment of cages and other surroundings of the shed were properly cleaned with disinfectant. Day old broiler chickens (30 in number) were purchased from Nourish Poultry and Hatchery Ltd. and brought in the experimental shed. Immediately after unloading from the chick boxes the chicks were given Vitamin-C and glucose to prevent the stress occurring during transport. The broiler chicks were kept in the same compartment for 7 days and brooding temperature were correctly maintained. The litter management was also done very carefully. The starter and finisher broiler rations were supplied to the broiler chicken appropriately

\subsection{Experimental Design}

After 7 days all the 30 broiler chicks were divided into 2 groups (A and B) for assessing the efficacy of tulsi leaves extracts as growth promoter on broilers. Chicks of group ' $A$ ': were kept as control and were not treated only fed basal diet. Chicks of group ' $B$ ': were fed basal diet supplemented with $3 \%$ tulsi leaves extracts through drinking water for next four weeks. Weekly feed consumption for each group was determined. Mean initial and weekly body weight of birds for 
each group was determined and then body weight gain was calculated. At the end of the experimental period, 5 birds from each replicate were weighed, numbered, and then ethically slaughtered. The weight of breast and thigh were recorded along with the vital organs (heart, liver, and gizzard). The data collected on the production cost of broiler were used to find out the commercial viability of the herbal growth promoter. The cost of production of the broiler in each group was calculated on per kg basis to work out the economics of production of the birds for each group.

Blood samples were collected from wing vein of chicken of both control and treated groups at $30^{\text {th }}$ days and the parameters of Total Erythrocyte Count (TEC), Hemoglobin Estimation (Hb), Packed Cell Volume (PCV), Erythrocyte Sedimentation Rate (ESR) were calculated with standard methods as described by Lamberg and Rothstein, [15].The data were analyzed statistically between control and treated groups of chicken by paired student " $t$ " test. The differences were considered statistically significant at $\mathrm{P}<0.05$.

\section{Results and discussion}

\subsection{Body weight gain, feed consumption and feed conversion ratio}

In control group (Group A), data regarding in initial average live weight on $1^{\text {st }}$ day was $42.80 \pm 10.31$ gm, final live weight $1530 \pm 33.07 \mathrm{gm}$, weight gain $1488 \pm 41.12 \mathrm{gm}$ and feed conversion ratio (FCR) was 1.91. In Group B initial average live weight on $1^{\text {st }}$ day was $42.68 \pm 6.90 \mathrm{gm}$, final live weight $1600 \pm 31.07 \mathrm{gm}$, weight gain $1551 \pm 39.29$ gm and FCR 1.73 . Result showed that birds of group B using drinking water were supplemented with 3\% tulsi caused statistically significant increase in higher body weight than control group (Table 1). This present study is also similar with Hossain et al. [16] who reported that boilers fed on diet containing neem and tulsi leaves, had higher body weight gain and better feed conversion ratio. Similarly, Nath et al. [17], Akter et al. [18] also reported significant increase in the live weight and feed efficiency of broilers compared with control group, which is in agreement with the findings of the present study (Table 2).

Table 1 Body weight gain of broiler

\begin{tabular}{|l|c|c|c|c|c|}
\hline $\begin{array}{c}\text { Body wt. } \\
(\mathbf{g m})\end{array}$ & $\begin{array}{c}\text { Day 1 } \\
\text { Mean } \pm \text { SD }\end{array}$ & $\begin{array}{c}\text { Day 7 } \\
\text { Mean } \pm \text { SD }\end{array}$ & $\begin{array}{c}\text { Day 14 } \\
\text { Mean } \pm \text { SD }\end{array}$ & $\begin{array}{c}\text { Day 21 } \\
\text { Mean } \pm \text { SD }\end{array}$ & $\begin{array}{c}\text { Day 30 } \\
\text { Mean } \pm \text { SD }\end{array}$ \\
\hline Control $(\mathrm{n}=10)$ & $42.80 \pm 10.31$ & $140 \pm 18.73$ & $486 \pm 13.70$ & $986.54 \pm 3.07$ & $1530 \pm 33.07$ \\
\hline Treatment $(\mathrm{n}=10)$ & $42.68 \pm 6.90$ & $141.50 \pm 12.13$ & $465 \pm 14.30$ & $1038.70 \pm 9.90$ & $1600 \pm 31.07$ \\
\hline \% increase & 0.00 & 10.19 & 11.39 & 13.98 & 16.43 \\
\hline
\end{tabular}

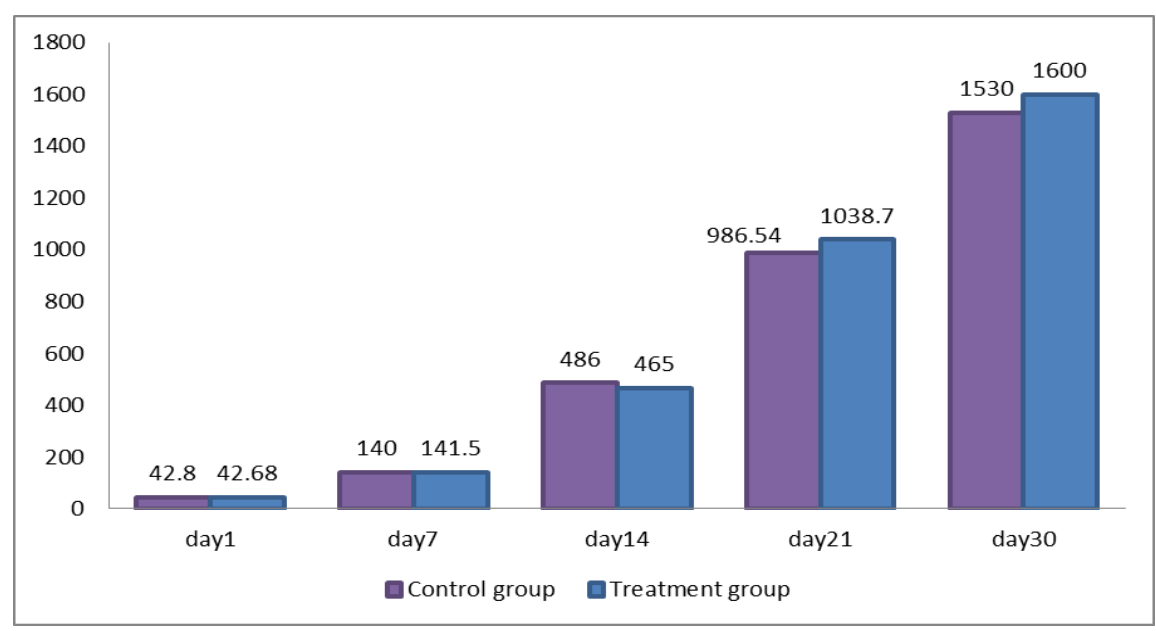

Figure 1 Body weight of experimental Broiler chicken

These results may be due to antibacterial, antimicrobial and anti-protozoal properties [9,10] of tulsi leaves, which help to reduce the microbial load, improved the feed consumption, and feed efficiency of the birds. 
Table 2 Initial and final live weight, weight gain, feed consumption and feed conversion ratio of broiler supplemented with or without tulsi leaves extract

\begin{tabular}{|c|c|c|c|c|}
\hline Variables & Treatments & $\begin{array}{l}\text { Average weight } \\
\text { (Mean } \pm \text { SEM) }\end{array}$ & $P$ value & $\begin{array}{l}\text { Significanc } \\
\text { e level }\end{array}$ \\
\hline \multirow{2}{*}{$\begin{array}{l}\text { Initial live weight (gm) on } 1^{\text {st }} \\
\text { day }\end{array}$} & Control & $42.80 \pm 10.31$ & \multirow[t]{2}{*}{0.000} & \multirow{2}{*}{$* *$} \\
\hline & Tulsi leaves extract (without) & $42.68 \pm 6.90$ & & \\
\hline \multirow{2}{*}{$\begin{array}{l}\text { Final live weight }(\mathrm{gm}) \text { on } 30^{\text {th }} \\
\text { day }\end{array}$} & Control & $1530 \pm 33.07$ & \multirow[t]{2}{*}{0.000} & \multirow{2}{*}{$* *$} \\
\hline & Tulsi leaves extract & $1600 \pm 31.07$ & & \\
\hline \multirow{2}{*}{ Weight gain from $7^{\text {th }}$ day (gm) } & Control & $1488 \pm 41.12$ & \multirow[t]{2}{*}{0.000} & \multirow{2}{*}{$* *$} \\
\hline & Tulsi leaves extract & $1551 \pm 39.29$ & & \\
\hline \multirow{2}{*}{ Feed consumption (gm) } & Control & $2922.30 \pm 35.49$ & \multirow[t]{2}{*}{0.000} & \multirow{2}{*}{$* *$} \\
\hline & Tulsi leaves extract & $2768.00 \pm 52.29$ & & \\
\hline \multirow{2}{*}{ Feed consumption Ratio (FCR) } & Control & \multicolumn{2}{|l|}{1.91} & \multirow{2}{*}{$* *$} \\
\hline & Tulsi leaves extract & \multicolumn{2}{|l|}{1.73} & \\
\hline
\end{tabular}

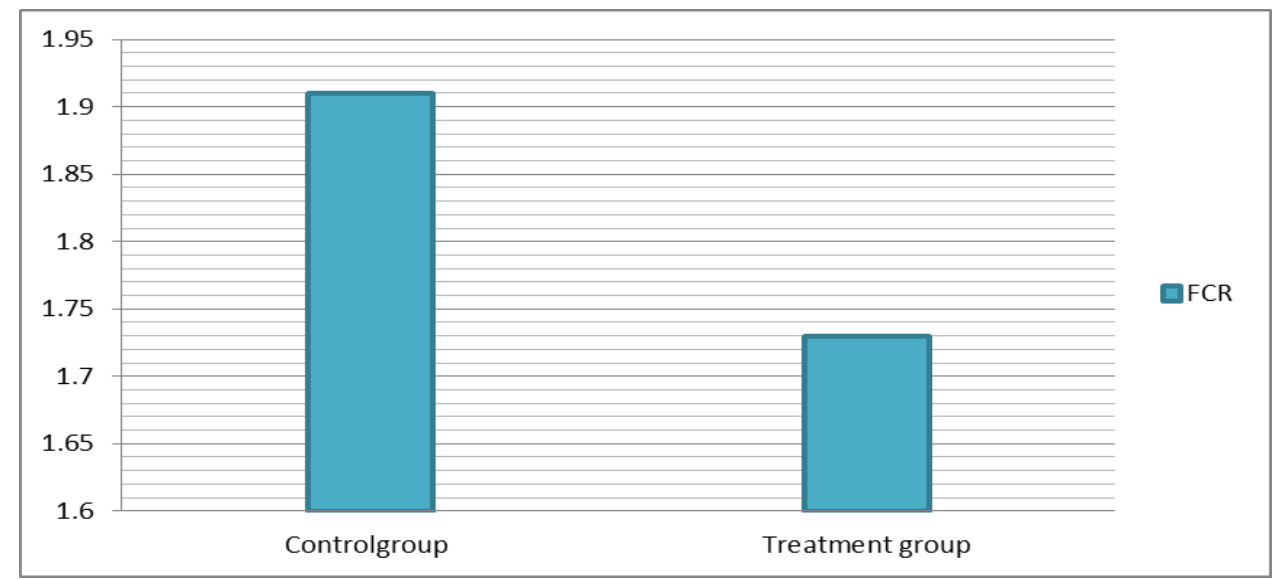

Figure 2 Comparison of Feed Conversion Ratio (FCR)

\subsection{Dressing percentage and weight of different body organs}

Data shows relatively insignificant in the dressing percentages of the birds of two groups (Table 3). Similarly, statistical analysis of the data did not show any difference between the relative gizzard weights of the birds of respective groups but showed 1\% level of significance of relative heart, liver, spleen and pancreas weight using drinking water with or without supplementation of tulsi leaves extract (Table 3). This results are also in accordance with the findings of Hernandez et al. [19], Alom et al. [20] who reported no differences in the mean weight of proventriculus, gizzard, intestine, liver and pancreas in broilers fed of two herbal plants extract. 
Table 3 Dressing percentages, relative giblet weight (heart, gizzard, liver and spleen) and pancreas weight of broiler supplemented with or without tulsi leaves extract from 1 to 30 days of age

\begin{tabular}{|c|c|c|c|c|}
\hline Variables & Treatments & $\begin{array}{r}\text { Average value } \\
\text { (Mean } \pm \text { SEM) }\end{array}$ & $P$ value & $\begin{array}{c}\text { Significance } \\
\text { level }\end{array}$ \\
\hline \multirow{2}{*}{ Dressing percentage } & Control & $63.411 \pm 0.413$ & \multirow{2}{*}{0.921} & \multirow{2}{*}{ NS } \\
\hline & Tulsi leaves extract & $63.570 \pm 0.911$ & & \\
\hline \multirow{2}{*}{ Relative heart weight } & Control & $0.426 \pm 0.031$ & \multirow{2}{*}{0.001} & \multirow{2}{*}{$* *$} \\
\hline & Tulsi leaves extract & $0.505 \pm 0.036$ & & \\
\hline \multirow{2}{*}{ Relative gizzard weight } & Control & $1.450 \pm 0.031$ & \multirow{2}{*}{0.602} & \multirow{2}{*}{ NS } \\
\hline & Tulsi leaves extract & $1.446 \pm 0.011$ & & \\
\hline \multirow{2}{*}{ Relative liver weight } & Control & $2.630 \pm 0.031$ & \multirow{2}{*}{0.002} & \multirow{2}{*}{$* *$} \\
\hline & Tulsi leaves extract & $2.658 \pm 0.030$ & & \\
\hline \multirow{2}{*}{ Relative spleen weight } & Control & $0.121 \pm 0.012$ & \multirow{2}{*}{0.011} & \multirow{2}{*}{$* *$} \\
\hline & Tulsi leaves extract & $0.132 \pm 0.012$ & & \\
\hline \multirow{2}{*}{ Relative pancreas weight } & Control & $0.234 \pm 0.013$ & \multirow{2}{*}{0.001} & \multirow{2}{*}{$* *$} \\
\hline & Tulsi leaves extract & $0.252 \pm 0.018$ & & \\
\hline
\end{tabular}

Relative weight (g) = Weight of organ / Live body weight of bird X 100

Dressing \% = Dressing weight of bird / Live weight of bird

\subsection{Economics of production}

The average rearing cost of broiler in two groups were Tk. 180.00 and Tk. 194.00 respectively (Table 4) excluding the cost of labor because the experiment was conducted on the Department of Pharmacology research shed, Bangladesh Agricultural University, Mymensingh. Miscellaneous cost summed up Tk. 25.00 per broiler, which included the estimated cost of electricity, litter and disinfectant. The average live weight/broiler in groups A and B were $1.530 \mathrm{~kg}$ and $1.600 \mathrm{~kg}$ respectively.

Table 4 Data showing economics of broiler production kept under treatment and control groups from day old to 30 days of age

\begin{tabular}{|l|c|c|}
\hline Description & $\begin{array}{l}\text { Group-A } \\
\text { (Control) }\end{array}$ & $\begin{array}{l}\text { Group-B } \\
\text { (Treatment) }\end{array}$ \\
\hline Cost/chick (tk) & 55.00 & 55.00 \\
\hline Average feed consumed (Kg)/chicks & 2.50 & 2.60 \\
\hline Feed price/kg (tk) & 40.00 & 40.00 \\
\hline Cost of herbal growth promoters (tk) & 0.00 & 10.00 \\
\hline Feed cost (tk)/chicks & 100.00 & 104.00 \\
\hline Miscellaneous (tk) & 25.00 & 25.00 \\
\hline Total cost/broiler (tk) & 180.00 & 194.00 \\
\hline Average live weight (Kg) & 1.53 & 1.60 \\
\hline Sale price/Kg live wt. (tk) & 130.00 & 130.00 \\
\hline Sale price/broiler (tk) & 217.50 & 246.00 \\
\hline Net profit/broiler (tk) & 37.50 & 52.00 \\
\hline Profit/ Kg live weight (tk) & 24.51 & 32.50 \\
\hline
\end{tabular}


The broilers were sold in live weight basis at the rate of Tk. 130.00/kg. So the net profit/Kg live weight in the respective group excluding the cost of labor was found to be Tk. 24.51 and Tk. 32.50 respectively. From this experiment, it is observed that tulsi leaves extract supplementation in the broiler rations may be useful for the safe, economical, and efficient production of broiler and reduce the cost of production by eliminating the use of vaccines and antibiotics similar observations were reported by Hossain et al. [16], Akter et al. [17]. This technique is easy to implement at field level as an alternative of commercial growth promoter.

\subsection{Hematological parameters}

The hematological parameter TEC, ESR and PCV value of treatment group showed significant difference, while hemoglobin estimation did not show significant difference between the treatment and control groups. Nagalakshmi et al. [21] and Gowda et al. [22] were also agreed that bitters principles of medicinal plants possess a strong influence on hematological traits particularly PCV and Hb of subjects depending on their nutritional status.

Table 5 Study of tulsi leaves extract on hematological parameters of broiler on 30th day

\begin{tabular}{|c|c|c|c|c|}
\hline Blood parameters & Treatments & $\begin{array}{l}\text { Average blood parameters value } \\
\text { (Mean } \pm \text { SEM) }\end{array}$ & $\begin{array}{c}\text { P } \\
\text { Value }\end{array}$ & Significance level \\
\hline \multirow{2}{*}{$\operatorname{TEC}\left(\mathrm{mm}^{3}\right)$} & Control & $244.62 \pm 1.058$ & \multirow{2}{*}{0.001} & \multirow{2}{*}{$* *$} \\
\hline & Tulsi leaves extract & $278.39 \pm 0.662$ & & \\
\hline \multirow{2}{*}{$\mathrm{Hb}(\mathrm{gm} / \mathrm{dl})$} & Control & $6.42 \pm 0.431$ & \multirow{2}{*}{0.222} & \multirow{2}{*}{ NS } \\
\hline & Tulsi leaves extract & $7.69 \pm 0.123$ & & \\
\hline \multirow{2}{*}{ PCV (\%) } & Control & $16.00 \pm 0.133$ & \multirow{2}{*}{0.001} & \multirow{2}{*}{$* *$} \\
\hline & Tulsi leavesextract & $17.92 \pm 0.012$ & & \\
\hline \multirow{2}{*}{ ESR $\mathrm{mm}$ in $1^{\text {st }}$ hour } & Control & $6.56 \pm 0.259$ & \multirow{2}{*}{0.002} & \multirow{2}{*}{$* *$} \\
\hline & Tulsi leaves extract & $5.24 \pm 0.651$ & & \\
\hline
\end{tabular}

NS- Not Significant; ${ }^{* *}$ - Significant Level; Values shows in the same column differ significantly $(\mathrm{P}<0.05)$.

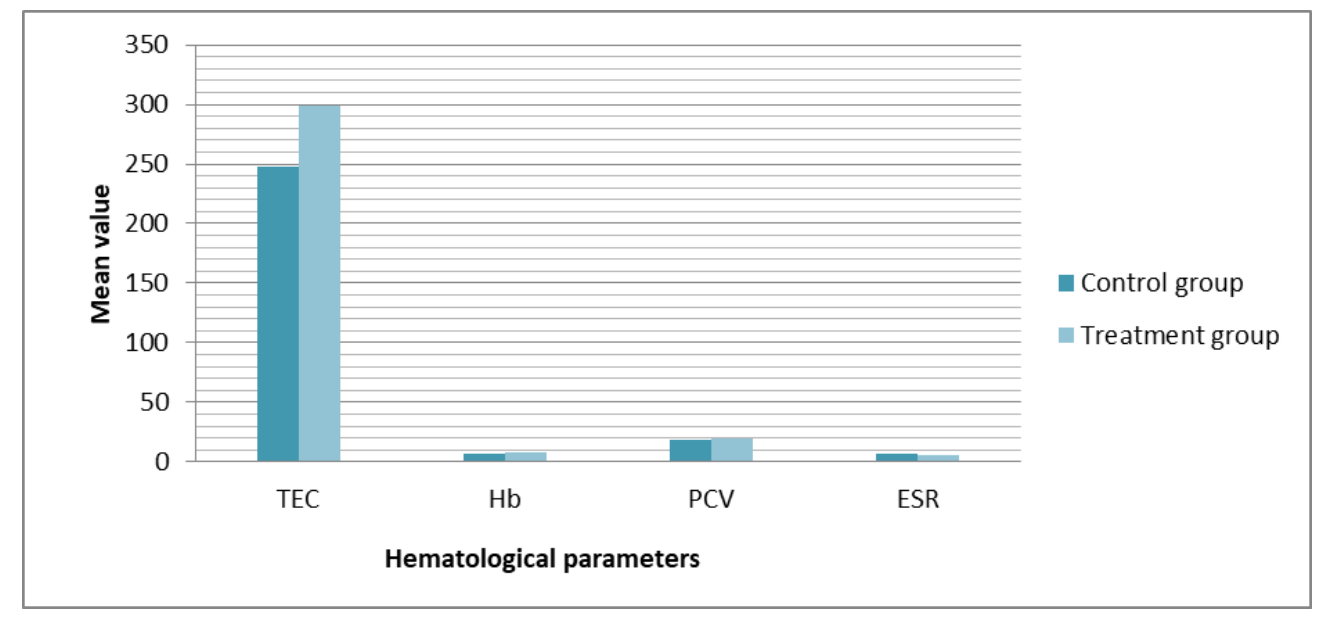

Figure 4 Different Hematological parameters of broiler

\section{Conclusion}

From the findings of this research, it can be concluded that supplementation of $3 \%$ tulsi leaves extract in the treatment group could be effectively used as a potential natural growth promoter and significantly improved the body weight gain, lower mortality, feed consumption, FCR and feed efficiency. This is a very short-term (only 30 days) experiment to evaluate the medicinal value of tulsi leaves extract. Before field application of tulsi leaves extract as growth promoter 
and as an alternative for antibiotics further trial on a large scale basis is needed. Also to make the findings more accurate and effective further study is essential to determine the different antibody levels in broilers of treated group.

\section{Compliance with ethical standards}

\section{Acknowledgments}

The author would like to thanks the Department of Pharmacology, Faculty of Veterinary Science, Bangladesh Agricultural University for giving the opportunity to study and complete this research smoothly.

\section{Disclosure of conflict of interest}

The authors state no conflict of interest.

\section{Statement of ethical approval}

The present research work does not contain any studies performed on animals/humans subjects by any of the authors.

\section{References}

[1] Singh MK, Singh SK, Sharma RK, Singh B, Kumar S, Joshi SK, Kumar S, Sathapathy S. Performance and carcass characteristics of guinea fowl fed on dietary Neem (Azadirachta indica) leaf powder as a growth promoter. Iranian Journal of Veterinary Research. 2015; 16(1): 78-82.

[2] Gaskins HR, Collier CT, Anderson DB. Antibiotics as growth promotants: mode of action. Animal Biotechnology. 2002; 13: 29-42.

[3] Nisha AR. Antibiotic residues: A global health hazard. Vet. World. 2008; 1(12).

[4] Lawal JR, Jajere SM, Geidam YA, Bello AM, Wakil Y, Mustapha M. Antibiotic residues in edible poultry tissues and products in Nigeria: A potential public health hazard. International Journal of Animal and Veterinary Advances. 20 Jul 2015; 7(3): 55-61.

[5] Cogliani C, Goossens H, Greko C. Restricting antimicrobial use in food animals: lessons from Europe. Microbe. 2011; 6(6): 274.

[6] Tavernise S. FDA restricts antibiotics use for livestock. The New York Times. 2013; 53-79.

[7] Afolabi C, Akinmoladun EO, Ibukun I, Emmanuel A, Obuotor EM, Farombi EO. Phytochemical constituent and antioxidant activity of extract from the leaves of Ocimum gratissium. Scientific Research and Essay. 2007; 2(5): 163-166.

[8] Doughari JK, Manzara S. In vitro antibacterial activity of crude leaf extracts of Mandifera Indica. African Journal of Microbiology Research. 2008; 2: 69-72.

[9] Joshi B, Lekhak S, Sharma A. Antibacterial property of different medicinal plants: Ocimum sanctum, Cinnamomum zeylanicum, Xanthoxylum armatum and Origanum majoran. Kathmandu University Journal of Science, Engineering and Technology. 2009; 5(1): $143-50$.

[10] Subramanian M, Chintalwar GJ, Chattopadhyay S. Antioxidant and radioprotective properties of an Ocimum sanctum polysaccharide. Redox Report. 2005; 10(5): 257- 64.

[11] Singh N, Verma P, Pandey BR, Bhalla M. Therapeutic potential of Ocimum sanctum in prevention and treatment of cancer and exposure to radiation: An overview. International Journal of Pharmaceutical Sciences and Drug Research. 2012; 4(2): 97-104.

[12] Mondal S, Mirdha BR, Mahapatra SC. The science behind sacredness of Tulsi (Ocimum sanctum Linn.). Indian J Physiol Pharmacol. 1 Oct 2009; 53(4): 291-306.

[13] Gupta S, Mediratta PK, Singh K, Sharma K, Shukla R. Antidiabetic, antihyper cholesterolaemic and antioxidant effect of Ocimum sanctum seed oil. Indian Journal of Experimental Biology. 2006; 44: 300-04.

[14] Bihari CG, Shankar NB, Kumar JP, Keshari PS, Ellaiah P. Phytochemical investigation and screening for anthelmintic activity of leafy extracts of various Ocimum (Tulsi) species. Journal of Pharmacy Research. 2010; 3(9): 2140-2141. 
[15] Lamberg SL, Rothstein R. Laboratory manual of hematology and urinalysis. AVI Pub. 1978.

[16] Hossain MS, Faruk MAZ, Das D, Das S. Effects of Neem (Azadirachta indica) and Tulsi (Ocimum sanctum) extract in the Growth Performance of Broiler with Economics of Production. J Vet Med Animal Sci. 2021; 4(1): 10-66.

[17] Nath DD, Rahman MM, Akter F, Mostofa M. Effects of tulsi, black pepper and cloves extract as a growth promoter in broiler. Bangladesh Journal of Veterinary Medicine. 2012; 10(1-2): 33-9.

[18] Akter MS, Das D, Faruk MAZ, Das S, Tuhin MRI. Comparative efficacy of neem and turmeric extracts as growth promoter in broilers. International Journal of Natural and Social Sciences. 2021; 8(1): 58-65.

[19] Hernandez F, Madrid J, Garcia V, Orengo J, Megias MD. Influence of two plant extracts on broilers performance, digestibility, and digestive organ size. Poultry science. 1 Feb 2004; 83(2): 169-74.

[20] Alom F, Mostofa M, Alam MN, Sorwar MG, Uddin J, Rahman MM. Effects of indigenous medicinal plant tulsi (Ocimum sanctum) leaves extract as a growth promoter in broiler. Research in Agriculture Livestock and Fisheries. 2015; 2(1): 97-102.

[21] Gowda SK. Neem (Azadirachta indica) kernel meal in the diet of White Leghorn layers. British poultry science. 1 Dec 1998; 39(5): 648-652.

[22] Nagalakshmi D, Sastry VR, Agrawal DK, Katiyar RC, Verma SV. Performance of broiler chicks fed on alkali-treated neem (Azadirachta indica) kernel cake as a protein supplement. British Poultry Science. 1 Sep 1996; 37(4): 809818. 